\title{
INVESTIGATING THE RELATIONSHIP BETWEEN BRAND ATTRIBUTES AND BRAND LOYALTY AMONG TOOTH PASTE USERS IN GREATER ACCRA REGION OF GHANA.
}

\author{
Edward Markwei Martey ${ }^{1 *}$, Joseph Frempong ${ }^{2}$ \\ *1Sumy Agrarian university, Sumy Ukraine, Email: edmarkwei@yahoo.co \\ ${ }^{2}$ Koforidua Polytechnic, Ghana, Kfrempyl@gmail.com
}

*Corresponding Author: -

*Email:edmarkwei@yahoo.co

\begin{abstract}
: -
The purpose of this study is to investigate the association between brand attributes and brand loyalty among tooth paste users in Greater Accra region of Ghana. The main objective is to examine the relationship between brand attributes on brand loyalty. Four hundred and twenty-one (421) copies of questionnaires were retrieved through convenient sampling method. With the aid of Statistical Package for Social Sciences (SPSS) the following statistics were employed:

Descriptive statistics, Cranach's alpha, Kurtosis and Skewness and Regression analysis were used to measure the relationship of independent variables (packaging, price, and brand awareness) on dependent variable (brand loyalty). The findings revealed that all three attributes of brand; packaging, price and brand awareness had a significant and positive relationship with brand loyalty. The research suggests that tooth-paste producers in Ghana should adopt green packaging marketing strategy to outwit multinational competitors.
\end{abstract}

Keywords: packaging; pricing; awareness; branding; consumer behavior

\section{(c) $(\$)$}




\section{INTRODUCTION}

This study is to investigate the relationship between packaging, price and brand awareness on brand loyalty. By definition, brand loyalty is the consumer's emotionally-charged decision to purchase a specific brand again and again. The consumer perceives that the brand meets their expectations and identifies with the consumer on a personal level. Brand loyalty is based on an emotional involvement that develops between the consumer and the brand. The consumer's perception is that the brand fulfills some kind of physical need or emotional want in such a unique way that some kind of emotion is evoked during the purchase process and while using the brand (Susan G. 2000). Decision making process to buy a product can be conscious or unconscious, but it is always based on trust that the brand will deliver on the consumer's expectations for it. Brand loyalists do not purchase a substitute brand if their preferred brand is not available. Customers would not mind to travel to multiple stores in search of their preferred brand and are more likely to forgo making a purchase if their brand cannot be found than they are to purchase a substitute (Susan G. 2000).

Brand loyalty is the mind-set that persuades a customer either to revisit a company, shop or outlet to purchase a particular product, service or brand there again. (Jessy John, 2010). All loyal customers build businesses by buying more, paying premium prices, and providing new referrals through positive word of mouth over time (Ganesh et al., 2000). Brand loyalty is closely related to the company's continued survival, and to a brawny future growth. Hence, for a company to maintain a stable profit level in a fierce competitive market striving to retain existing customers is more important than an aggressive one, which expands the size of the overall market by inducing potential customers (Ahmad and Buttle, 2002). It is always cheaper to retain existing customers than it is to acquire new customers, and brand loyalists aren't just repeat purchasers. They are also vocal brand advocates that create word-of-mouth marketing which turns into new business. Building brand loyalty should be a strategic imperative for every business (Susan G. 2000).

Product-related attributes associated with packaging, pricing and brand awareness, inter alia, tend to create and reinforce the relationship between the consumer and the brand (Suresh et al. 2012). Consumers respond to packaging based on a set of prejudices, learned reactions and individual preferences that help to catapult certain products to dominance in today's dynamic markets (Aaker, 2010). Certain shapes, colours, sizes and textures naturally influence consumers to respond positively, whilst others evoke negative reactions (Aaker, 2010).

\section{LITERATURE REVIEW}

Shopping around is time and energy consuming, and most consumers do not always possess enough product knowledge to ensure the best buy. Under such circumstances, consumers usually purchase well-known brands, which may result in higher costs but requires less research efforts. Thus, brand image not only affects how consumers view a product but has the benefit of lowering purchase risks (London et al. 2008). According to Rowley (2005) opportunities are exhibited through the increased emphasis placed on improving the quality of packaging, maintaining competitive pricing and creating loyalty amongst customers. Product-related attributes associated with packaging, pricing and brand awareness, tend to create and reinforce the relationship between the consumer and the brand (Suresh et al. 2012).

\section{Brand attribute constructs Packaging}

Packaging may be perceived as a family of activities that are concerned with the design, production and filling of a container or wrapper of the product item in such a way that the product can be effectively protected, stored, transported and identified, as well as successfully marketed (Kent and Omar 2003). An often-overlooked component to identify the packaging of a particular manufacturer standing on the shelf distinguishes it from other competing brands (Cronje et al. 2003). Wright (2006) also acknowledges that packaging is effective in marketing products since most consumers are greatly affected by appearances and design of the product, in addition to other aspects such as touch, taste, texture and smell.

Packaging appears to be one of the important factors in purchase decisions that are made at the point of sale where it becomes an essential part of the selling process (Silayoi and Speece, 2004). In current competitive retail environments, consumers are exposed to a plethora of messages on packaging and merchandising (Klevas, 2005). When consumers are spoiled for choice in terms of the available product range, they rely on product externalities, such as packaging, as signals of perceived quality (Rundh, 2005). This presents marketing with a challenge to depend heavily on the visual communication of packaging to inform and persuade consumers, both at the point of purchase and at the point of consumption (McNeal and Ji, 2003). Communicating the right product and brand values on packaging is paramount in order to achieve the appropriate level of aesthetics and visual impact (Mowen and Minor, 2001). With the move to self-service retail formats, packaging increases its key characteristic as the 'salesman on the shelf' at the point of sale (Silayoi and Speece, 2004).

\section{Price}

Price, which is an enduring element of the original Ps of the marketing mix, may generally be perceived in terms of the specific monetary value that a customer attaches to goods and services (Kent and Omar, 2003) ). Goods and services must be priced in a way that achieves profitability for the company and satisfies customers, in addition to adapting to various constraints such as competition (Sahay, 2007). Price presents a unique opportunity to create loyalty, retain existing customers and attract prospective customers (Sahay, 2007). 
In this way consumers evaluate whether a price is too low or too high as they make their product choices. When a consumer perceives that a retailer charges high prices for a product, the consumer also perceives that the retailer possesses an air of luxury, which may lead to repeat purchases (Dunne and Lusch, 2008; Yesawich, 2004). This strategy is premised on the view that for some consumers, high price simply means giving up more resources for the product whereas some consumers perceive that high prices are a signal of better quality and prestige (Jin and Sternquist, 2003). Overall, it is important for marketers to choose price communication strategies, both at the point of sale and by the means of various media forms, which are capable of drawing consumers' attention to the product's value and thus inducing them to buy (Romani, 2006).

\section{Brand awareness}

Brand awareness is an important indicator of consumers' knowledge about a brand, the strength of a brand's presence in the consumers' minds and how easily that knowledge can be retrieved from memory (O'Guinn, Allen and Semenik, 2009). There are two main types of brand awareness, namely 'aided awareness' and 'top of the mind awareness' (Farris et al. 2010). Aided awareness occurs when a consumer is provided with a list of brand names and they recognize the brand from the given set whereas 'top of the mind awareness' occurs when the name of the brand is automatically recollected because the consumer very promptly associates the brand with the product category (Keller, 2008). Brand awareness influences consumer decision-making in various ways. For instance, consumers may use brand awareness as a nominal anchor in their purchase decisions (Hoyer and Brown, 1990). When consumers know a certain brand, they tend to include that name in their personal consideration set (MacDonald and Sharp, 2000).

\section{Brand loyalty}

Brand loyalty is a measure of the extent to which consumers are loyal to a particular brand over a period of time, which emphasizes a consistent repurchase of the same brand (Sheth and Mittal, 2004). Brand loyalty results in an emotional attachment to the brand, which is driven primarily by commitment and affection (Hawkins, Best and Coney, 2001; Seetharaman, Nadzir and Gunalan, 2001). The consumer develops affection for the brand in a manner similar to a friendship (Ball, Coelho and Machas, 2004). Brand loyalty can develop through identification; the consumer believes the brand reflects and reinforces some aspects of the consumer's selfconcept (Petromilli, Morrison and Million, 2002. A positive brand performance experience may seek that reward again through repeated usage (McKee, 2010).

Brand loyalty arises from habit and long history of brand usage (Chaudhuri, 1995; Neslin, 2002). For example, a consumer who used a particular brand five years ago and had a good experience with it in terms of quality and performance is more likely to use the same brand today and in the future (Briesch, Chintagunta and Fox, 2009). Furthermore, if consumers saw a brand being used in their parental home as they were growing up, they are likely to view this long history of use by parents as testimony to the brand's goodness and are likely to maintain its usage (Sheth and Mittal, 2003). Positive word-of-mouth communications from a committed customer increases both the probability of the recipient becoming a customer and of the recipient sharing the positive comment with a third person (Hawkins et al. 2001). Even when loyal customers purchase a different brand to take advantage of a promotional deal, they generally return to their original brand for their next purchase (Chaudhuri and Holbrook, 2001).

\section{Relationship between brands attributes and brand loyalty}

A study conducted by Bed (2008), which focused on existing practices of branding, packaging and labeling of new products in consumer product manufacturing units, reveals that the right packaging can help a brand to carve a unique position in the marketplace and in the minds of consumers. Hysen and Mensur (2008) reveal that packaging has a great positive effect on the purchase of dairy products. Ahasanul and Ali (2009) also found that packaging plays an important part in its latent ability to reflect the product attributes to unsuspecting and otherwise disinterested consumers (Gonzalez and Twede, 2007). Most of the packaging decisions affect how consumers associate themselves with a firm's products (Del Rio, Vazquez and Iglesias, 2001). Packaging also adds exceptional value to products (Underwood, Klein and Burke, 2001) and is a vital product differentiation tool that has a beneficial stimulus effect on the buying behavior of consumers (Wells, Farley \& Armstrong, 2007). It attracts the consumers' attention to a particular brand, enhances its image and influences consumers' perceptions about a product (Vila and Ampuero, 2007).

Price is one of the tools marketers may use to confront the market, either by directly attracting and retaining clients or fighting against competitors (Boonlertvanich, 2009). Moreover, price presents a unique opportunity to create loyalty, retain existing customers and attract prospective customers (Sahay, 2007). An assortment of pricing strategies may be employed to manipulate the purchase behavior of consumers (Cataluna, Franco \& Ramos, 2005). Wellknown brand is likely to perform better in the marketplace than a lesser-known brand (Yoo, Donthu and Lee, 2000). Brand awareness therefore has the effect of increasing brand market performance (Huang and Sarigöllü, 2012). These insights demonstrate that brand awareness is also an important contributor to the purchase decisions of consumers. 
Based on reviewed literature conceptual frame work was designed

\title{
Conceptual frame work
}

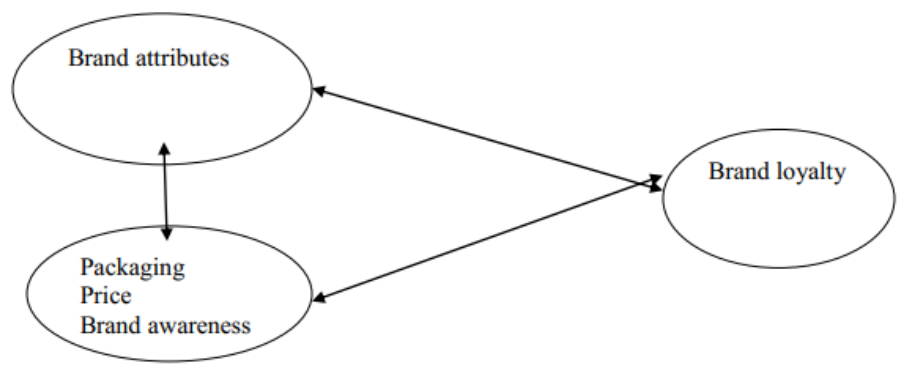

Fig.1: Relationship between brand attributes and brand loyalty

\author{
The research hypothesis was as a result of literature reviewed and conceptual frame work. \\ Research Hypotheses \\ H1: There is a significant positive relationship between packaging and brand loyalty \\ $\mathrm{H} 2$ : There is a significant positive relationship between price and brand loyalty \\ H3: There is a significant positive association between brand awareness and brand loyalty
}

\section{Problem of the study}

Research shows refusal to brush teeth regularly result to tooth decay. The human's mouth hides bacteria capable of affecting other parts of the body through the bloodstream. The Ghanaian tooth paste market is made of both local and foreign brands for customers to select from: Colgate, Crest(toothpaste), Armand, Hammer, Bainca(brand), Closeup, Pepsodent, Aqua fresh, Babool, Cibaca, Darlie, Doramad, Radioactie (toothpaste), Elmex, Euthymol, Solidox(toothpaste), Sensodymen, Signaln(toothpaste), Sozodont, Stomatoli, Panaalodont, Kolynos, Pepsodent, Ritadent, Anitadent, Promise(brand), Rembrandt(toothpaste) and Mentadent to mention but a few. This has resulted into fierce competition. Marketers have no choice than to directly attract and retain clients or fighting against their competitors (Boonlertvanich, 2009). Well-known brand is likely to perform better at the marketplace than a lesser-known brand (Yoo, Donthu and Lee, 2000). An assortment of marketing strategies needs to be employed to manipulate the purchase behavior of consumers in this situation. (Cataluna, Franco and Ramos, 2005). According to Hysen and Mensur (2008) packaging has a great positive effect on the purchase of product.

Brand loyalty is the company's continued survival, and future growth. Hence, for a tooth paste manufacturers and importers to maintain a stable profit level in a fierce competitive market striving to retain existing customers is more important (Ahmad and Buttle, 2002). However, there has been no or little effort to investigate factors that lead to brand loyalty in the tooth paste industry. The study holds answer to what are the construct of brand loyalty in the tooth paste industry in Ghana?

\section{Objectives of the study}

The purpose of this study is to examine the association between brand attributes and brand loyalty. The specific research objectives of the study are:

- To evaluate the relationship between packaging and brand loyalty $\square$ To investigate the relationship between pricing and brand loyalty

- To access the relationship between brand awareness and brand loyalty

\section{METHODOLOGY}

Both primary and secondary data were used in the study. The study adopted purposive sampling technique to select shopping centers whereas convenience sampling techniques were employed to select a tooth paste customer. The suitable sampling technique for this study is non-probability technique using convenience sampling. This is due to the difficulty in determining the specific list of customers.

\section{Participants}

The target population comprised consumers who purchased various brands of tooth paste and falls between the ages of 18 and 60. Besides, 421 out of the 600 individuals who were requested to participate in the study returned the questionnaires. Respondents were recruited from Tema and Accra Shopping Mall and A\&C shopping mall in the Greater Accra Region of Ghana.

\section{Data collection}

Data were collected through the use of a structured questionnaire. The questionnaire was divided into five sections. Section A elicited general and biographical information about respondents. Section B elicited information on respondents' perceptions of packaging; section C sought information on respondents' perceptions of price. The questions in Section D sought information on brand awareness and Section E sought information on brand loyalty. The questionnaire was administered on three consecutive holidays, Farmers' day, Christmas day and Boxing Day all in the month of December 2012. Holidays were selected as they are the busiest shopping days in Ghana. Once the data is collected and entered to 
computer using SPSS. The following statistics were used: Descriptive statistics in order to have clear picture of study variables. Cronbach's alpha, which measures the internal consistency of a construct, Kurtosis and Skewness values were used to check the normality of each variable used in the research. Regression analysis was used to measure the effect of independent variables on dependent variable.

\section{Regression analysis}

Regression analysis was undertaken in order to examine the correlation more closely and to examine the effects of the independent variables on the dependent variable. To test predictive relationships, packaging, price and brand awareness were used as the independent variables and brand loyalty was used as the dependent variable.

Table 2. Supporting literature for measurement scales.

\begin{tabular}{|l|l|}
\hline Construct & scales \\
\hline Packaging & {$[41,56]$} \\
\hline Price & {$[44,48]$} \\
\hline Brand awareness & {$[49,58]$} \\
\hline
\end{tabular}

All of the measurement scales used, as indicated in Table 2, were based on previous research. Assuring the validity and reliability of the measures required supporting literature to validate the scales which were used in the research constructs. The customer retention construct was measured using the scales and indices included in the work of (Suresh et al. 2012) who used the following variables to determine the construct of brand attributes: price, packaging, labeling, brand image, quality and brand awareness. As shown in Table 2, internal marketing construct were measurement scales adapted from previous studies.

\section{Sample composition}

Amongst the respondents, 54\% were female and $46 \%$ were male. A majority of the respondents (64\%) were aged between 25 and 45 years. Furthermore, approximately $51 \%$ of respondents were married, $46 \%$ were single and $3 \%$ were either divorced or widowed. With regard to the frequency of buying tooth paste, approximately $45 \%$ of respondents attested to the fact that they ordinarily buy tooth paste once in a cycle of one month approximately $37 \%$ attested that under ordinary circumstances, they buy tooth paste twice in a cycle of one month whilst $18 \%$ of the respondents attested that they buy tooth paste once in a cycle of three weeks.

Table 3. Values of Cronbach's alpha for the research construct

(Source field work, 2013)

\begin{tabular}{|l|l|}
\hline Construct & Value \\
\hline Packaging & 0.635 \\
\hline Price & 0.706 \\
\hline Brand awareness & 0.834 \\
\hline
\end{tabular}

A reliability test was carried out using Cronbach's alpha, which measures the internal consistency of a construct. The recommended minimum acceptable limit of reliability measure, as reported by (U. Sekaran, 2003) is 0.60. As shown in Table 3, all the constructs passed the reliability test.

Table 4. Descending means of the constructs Customer loyalty

(Source field work, 2013)

\begin{tabular}{|l|l|l|}
\hline Construct & Mean & Standard deviation \\
\hline Packaging & 4.054 & 0.764 \\
\hline Price & 4.765 & 0.876 \\
\hline Brand awareness & 4.097 & 0.534 \\
\hline
\end{tabular}

The result shown in Table 4 indicates frequency and descriptive statistics used to determine the relative importance of each of the constructs. The competitive priorities shown in Table $\mathbf{4}$ have a mean above 4 . Therefore it concludes that all of the constructs are of significant importance to the study.

Table 5. Skewness and Kurtosis for research constructs. Variable

(Source field work, 2013)

\begin{tabular}{|l|l|l|}
\hline Variable & Skewness & Kurtosis \\
\hline Packaging & -0.345 & -0.504 \\
\hline Price & -0.254 & -0.07 \\
\hline Brand awareness & -0.532 & -0.65 \\
\hline
\end{tabular}


From Table 5, Kurtosis and Skewness values were used to check the normality of each variable used in the research. Skewness values larger than $(+1)$ or smaller than $(-1)$, as suggested by Hair J., Babin B., Money A. and Samuel P. (2003) indicate a substantially skewed distribution. Besides according to Hair J., Anderson R., Tatham R. and Black W. (1998) added that a curve is too peaked when the Kurtosis exceeds $(+3)$ and is too flat when it is below $(-3)$. This means Skewness values within the range of $(-1)$ to $(+1)$ and Kurtosis values within the range of $(-3)$ to $(+3)$ indicate an acceptable range. As shown in Table 5, the values of Skewness and Kurtosis for each variable indicates that the research constructs fell within the acceptable range.

Table 6. Model summary

(Source field work, 2013)

\begin{tabular}{|l|l|l|l|}
\hline Model & R & R Squared & Std. Error of the Estimate \\
\hline & 0.721 & 0.691 & 0.175 \\
\hline
\end{tabular}

The results of the multiple regression analysis, as shown in Table 6, R determines the correlation between brand attributes and brand loyalty. These explain that the correlation between the two variables is .0721 which signifies a strong positive relationship. Besides, the result reveals a coefficient of determination, R2, which predicts the relationship between the independent variables and dependent variable, of 0.691 . This means that 69.1 percent of the total variance in the dependent variable (brand loyalty) is accounted for by the independent variables (packaging, price and brand awareness). This result affirms that the three construct of brand attribute is significant in creating brand loyalty.

Table 7. ANOVA result model

\begin{tabular}{|l|l|l|l|l|l|l|}
\hline \multirow{2}{*}{ Model } & & $\begin{array}{l}\text { Sum of } \\
\text { Squares }\end{array}$ & df & $\begin{array}{l}\text { Mean } \\
\text { Square }\end{array}$ & F & \multirow{2}{*}{\begin{tabular}{l} 
Sig. \\
\cline { 1 - 6 }
\end{tabular}} \\
& Regression & .865 & 2 & .432 & 110.014 & $.000(\mathrm{a})$ \\
& Residual & 75.254 & 199 & .378 & & \\
& Total & 76.119 & 201 & & & \\
\hline
\end{tabular}

a) Predictors: (Constant), pricing, brand awareness

b) Dependent Variable: brand loyalty

(Source field work, 2013)

The results of the F-ratio, as shown in Table 7, indicates that the regression model is significant at $p<0.001$. It can be concluded, that the regression model predicts brand loyalty strongly. In other words, brand attributes construct: packaging, price, and brand awareness (the independent variables) have the ability to predict customer loyalty (the dependent variable).

Table 8. Results of multiple regression analysis

\begin{tabular}{|c|c|c|c|c|c|c|}
\hline \multirow[b]{2}{*}{ Model } & & \multicolumn{2}{|c|}{$\begin{array}{l}\text { Unstandardized } \\
\text { Coefficients }\end{array}$} & \multirow{2}{*}{$\begin{array}{l}\text { Standardized } \\
\text { Coefficients } \\
\text { Beta }\end{array}$} & \multirow[b]{2}{*}{ t } & \multirow[b]{2}{*}{ Sig. } \\
\hline & & B & Std. Error & & & \\
\hline & (Constant) & 4.492 & .344 & & 6.790 & .000 \\
\hline & packaging & .085 & .056 & 0.37 & 4.105 & .000 \\
\hline & pricing & .081 & . 088 & 0.35 & 5.919 & .000 \\
\hline & $\begin{array}{l}\text { Brand } \\
\text { awareness }\end{array}$ & -.131 & .101 & 0.38 & 3.405 & \\
\hline
\end{tabular}

a) Dependent Variable: brand loyalty

(Source field work, 2013)

The regression analysis presented in Table 8 reveals that the creation of brand loyalty is determined by brand attribute; packaging, price and brand awareness. Packaging has a beta value of 0.37 . This means that Packaging explains $37.0 \%$ of the creation of brand loyalty, at a p-value of .000. This explains a significant association of Packaging with brand loyalty. Pricing has a beta value of 0.35 . This means that Pricing explains $35.0 \%$ of the creation of brand loyalty, at a p-value of 0.000.This indicates a significant association of pricing with loyalty brand. Brand awareness has a beta value of 0.38 . This means brand awareness explains $38.0 \%$ of the creation of brand loyalty, at a p-value of 0.000 . This shows a significant association of brand awareness with brand loyalty. Regression model is significant at $\mathrm{p}<0.001$. Therefore, all the hypothesized relationships between brand attributes and brand loyalty are accepted. Table 9 summarizes the research hypotheses and their results. 
Table 9. Summary of research hypotheses and results

\begin{tabular}{|l|l|l|l|l|}
\hline Hypothesis & Description & Beta & $\begin{array}{l}\text { t- } \\
\text { value }\end{array}$ & Comment \\
\hline H1 & $\begin{array}{l}\text { There is a significant positive relationship } \\
\text { between packaging and brand loyalty }\end{array}$ & 0.37 & 4.105 & Accepted \\
\hline $\mathbf{H 2}$ & $\begin{array}{l}\text { There is a significant positive relationship } \\
\text { between price and brand loyalty }\end{array}$ & 0.35 & 5.919 & Accepted \\
\hline $\mathbf{H 3}$ & $\begin{array}{l}\text { There is a significant positive relationship } \\
\text { between brand awareness and brand loyalty }\end{array}$ & 0.38 & 3.405 & Accepted \\
\hline
\end{tabular}

(Source field work, 2013)

\section{DISCUSSIONS}

The first hypothesis showed packaging correlating positively with brand loyal. This supports the claim made by Hysen and Mensur (2008) that packaging determines brand loyalty. They explore the relationship between packaging and brand loyalty on of a sample 82 shoppers. They revealed that packaging relates positively with brand loyalty. Besides Silayoi and Speece (2004) conducted a study on a purposively selected sample of 158 students to study the relationship between packaging and brand loyalty. They concluded that good packaging have high brand loyalty scores and vice versa.

The second hypothesis was accepted because a significant relationship was established. This result is consistent with the findings of (Boonlertvanich, 2009; Sahay, 2007), they indicated that price of a product attracts new customers and retains existing customers to a brand.

The third hypothesis was accepted because a positive relationship was established. This suggests that the higher the brand awareness level, the higher brand loyalty score. The result is consistent with a study conducted by Huang \& Sarigöllü, (2012). Their research was on brand awareness and brand loyalty among retail shopper. (Ball et al. 2004; Campo \& Yague, 2007; Underwood et al. 2001).

\section{Recommendations}

Tooth paste producers in Ghana should adopt a lean and green marketing strategy in packaging. Besides engage customers and build long-term relationships through a two-way dialogue such as community relation activities, sponsorship of local festivals and educational programs

Marketer should create good perception about their brand through realistic advertising. This is because profitable customers are born when a powerful brand's promise is fulfilled by a brand experience that exceeds expectations. Besides, producers of tooth paste should design different brands of paste for children, adult and the aged, currently there is one size and taste for all. Even though all the brands contain fluoride, it does not make the brands the same; certainly, marketers should emphasize on what makes their products different such as price, packaging and brand image so as to gain competitive advantage. Most tooth paste adverts in Ghana is about a Dentist endorsing a brand of paste to potential customers. The studies suggest that it is time to use celebrities as well. Their appearance, trustworthy, credibility and personality influence purchases.

\section{Conclusion}

The purpose of the study was to investigate the relationship between brand attribute and brand loyalty. Based on the regression analysis on the data obtained from a sample of tooth paste consumers, the research concluded that there is a significant positive relationship between brand attribute and brand loyalty

\section{Limitation and future research}

This research focuses on one Region of the country; therefore, further research in other regions may be necessary before generalization can be made on the entire country. Though convenience sampling method was adopted to select respondents it was not easy to catch the respondent's attention.

\section{REFERENCES}

[1].Bed, S., 2008, 'New consumer products branding, packaging and labeling in Nepal', The Journal of Nepalese Business Studies 5 (1), 98-119

[2].Boonghee, Y., Naveen D and Sungho L (2000) An Examination of Selected Marketing

[3].Mix Elements and Brand Equity, Journal of the Academy of Marketing Science Vol 5

[4].Chaudhuri, A. and Holbrook B. (2002), "The Chain of Effects from Brand Trust ... and Loyalty in Relational Exchanges," Journal of Marketing, Vol 2

[5].Chintagunta, P. and Fox, E. (2009) How Does Assortment Affect Grocery Store Choice? Journal of Marketing Research: April 2009, Vol. 46, No. 2, pp. 176-189.

[6].Hair, J., F. Jr Bush, R. P. \& Ortinau, D. J., 2000, marketing research: a practical approach for the new millennium, Irwin, McGraw-Hill, New York

[7].Hair, J. B. Babin, A. Money and P. Samuel, (2003) “Essentials of Business Research Methods,” Lehigh Publishing. 
[8].Hair, J., R. Anderson, R. Tatham and W. Black, (1998) "Multi-variate Data Analysis,” 5th Edition, Prentice-Hall, Upper Saddle River, 1998.

[9].Hysen, B. \& Mensur, V. (2008), 'Analysis of consumer behavior in regard to dairy products in Kosovo', Agricultural Research 46(3), 111-126.

[10]. Jin, B. \& Sternquist, B., 2003, 'The influence of retail environment on price perceptions', Journal of International Marketing Review 20(6), 643-660.

[11]. L.E. Wells, H. Farley, G.A. Armstrong, (2007) "The importance of packaging design for own-label food brands", International Journal of Retail \& Distribution Management, Vol. 35 Iss: 9, pp.677 - 690

[12]. (Keller, P. et al. ( 2008), Effects of Brand Awareness on Choice for a Common, Repeat- Purchase Product Journal of Consumer Research Vol. 17, No. 2 (Sep., 1990), pp. 141- 148

[13]. Michael Petromilli, Dan Morrison, Michael Million, (2002) "Brand architecture: building brand portfolio value", Strategy \& Leadership, Vol. 30 Iss: 5, pp.22 - 28

[14]. Mitul, M. et al. (2012) commercial use, distribution, and reproduction Global Journal of Management and Business Research vol. 12

[15]. Mitul, M. and Bhavesh, J. (2011) role of packaging on consumer buying behavior proceedings for 2011 international research conference and colloquium

[16]. O’Guinn, Allen and Semenik ( 2009) "Beyond Functional Benefits," Business \& Economics Marketing News, September 30, 2009, 23, 24

[17]. Silayoi, P. and Speece, M. (2007) "The importance of packaging attributes: a conjoint analysis approach", European Journal of Marketing, Vol. 41 Iss: 11/12, pp.1495 - 1517

[18]. Rajput, A. A., Kalhoro, S. H. \& Wasif, R., 2012, 'Impact of product price and quality on consumer buying behavior: Evidence from Pakistan', Interdisciplinary Journal of Contemporary Research in Business 4 (4), 485-496

[19]. Romani, S., 2006, 'Price misleading advertising: Effects on trustworthiness toward the source of information and willingness to buy', Journal of Product and Brand Management 15 (2), 130-138.

[20]. Rettie, R. \& Brewer, C. (2000), 'The verbal and visual components of

[21]. Package design', Journal of Product and Brand Management 9(1), 56-70.

[22]. Rundh, B. (2005), 'The multi-faceted dimension of packaging', British Food Journal107 (9), 670-684

[23]. Rowley, J. (2005), 'The four Cs of customer loyalty', Journal of Marketing Planning and Intelligence 23 (6), 574 581

[24]. Silayoi, P. \& Speece, M., 2007, 'The importance of packaging attributes: A conjoint analysis approach', European Journal of Marketing 41 (11/12), 1495-1517.

[25]. Sahay, A., 2007, 'How to reap higher profits with dynamic pricing', MIT Sloan Management Review48, $53-60$

[26]. Silayoi, P. \& Speece, M., 2004, 'Packaging and purchase decisions: an exploratory study on the impact of involvement level and time pressure', British Food Journal 106 (8), 607-628

[27]. Suresh, S., Mohanam, P. \& Naresh, G., 2012, 'Brand success redefined: An analysis of the interrelationships among various brand dimensions', Psychological Research 2 (1), 32-39

[28]. Sekaran, U. (2003), "Research Methods for Business: A Skill Building Approach," $4^{\text {th }}$ Edition, John Wiley and Sons, New York.

[29]. Seetharaman, Zainal Azlan Bin Mohd Nadzir, S. Gunalan, (2001) "A conceptual study on brand valuation", Journal of Product \& Brand Management, Vol. 10 Iss: 4, pp.243-256

[30]. Shahram, G., Mohammad, T. and Azizi, N. (2013) Investigating Effect of Marketing Mix on the Willingness of Students to Participate in Private Class International Journal of Business and Behavioral Sciences Vol. 3, No.7

[31]. Wright, J. (2006) the Yield Curve and Predicting Recessions, Research \& Statistics and Monetary affairs 